\title{
TESTBEN ÉRTETT GONDOLAT - SZÍNHÁZI MÓDSZEREK AZ OKTATÁSBAN
}

\section{MENTAL ACTION AS VISIBLE BODILY PERFORMANCE: AN EDUCATIONAL PERSPECTIVE}

\author{
Jean-Rémi Lapaire \\ kutatóprofesszor, Université Bordeaux Montaigne, Bordeaux, France \\ jrlapaire@u-bordeaux-montaigne.fr
}

\begin{abstract}
ÖSSZEFOGLALÁS
A kinetikus tevékenység serkenti a kognitív tevékenységet, és segíti a gondolatok kifejezését. Nemcsak a színész vagy a szónok támasztja alá testét, beleadva fizikailag a mondanivalóját, hanem a hétköznapi beszélő is "kézzel-lábbal” magyaráz: testét is használja elvont jelentések szóba foglalásakor. Mindhárman szimbolikus teret teremtenek, gesztusaik révén öltenek alakot fogalmaik, és jutnak célba üzeneteik. Mivel a tanár nyilvános beszélő, azt várhatnánk, hogy ura testének, és mesterien bánik kifejező mozdulataival. De ritkán kap formális képzést a retorika, a gesztusok szemiotikája vagy a pragmatika terén. Így a legtöbb oktató tanító teste és diákjaik tanuló teste rendre gyengén szerepel a tanteremben. Írásomban javaslok néhány stratégiát, amelyek révén tanár és tanuló színész lehet, a tanulás tere pedig előadásuk tere. Vázolom azt a szemléletet, amely szerint a tanteremben zajló érvelés és megértés testi tapasztalatokhoz köthető, és megmutatom, miért kellene több érzékleti-mozgásos, szenzomotoros foglalkozásba bevonni a tanulókat a közép- és felsőoktatásban.
\end{abstract}

\section{ABSTRACT}

Kinetic activity fuels cognitive activity and facilitates the expression of thought. Ordinary speakers, not just actors and orators, physically engage in argumentation and use their bodies to articulate abstract meanings. All make a symbolic use of space and gesture to shape ideas and deliver their messages. Because teachers are public speakers, one would normally expect them to control their bodily actions and expressive movements with great professional skill. But few have received any formal training in rhetoric, gesture semiotics or pragmatics. As a result, the teaching bodies of most instructors and the learning bodies of their students tend to underperform in the classroom. Strategies for turning teachers and learners into actors, and learning space into performance space, are suggested in this paper. An embodied approach to reasoning and understanding in the teaching room is outlined, and the case is made for greater sensory-motor engagement in secondary or higher education.

${ }^{1}$ Fordította: Szalai Éva 
Kulcsszavak: gesztus, testesültség, előadás, absztrakció, multimodalitás, oktatás

Keywords: gesture, embodiment, performance, abstraction, multimodality, education

Színház az egész világ,

És szinész benne minden férfi és nö.

William Shakespeare: Ahogy tetszik, II. felvonás, 7. szín

\section{BEVEZETÉS}

Sután mocorogva, gügyörészve lépünk az élet színpadára, de hamar kibontakozik társas lényünk, kezdünk ügyesebben bánni a szavakkal és mozdulatokkal, hiszen befogadjuk, „internalizáljuk” annak a társadalomnak-kultúrának a „kommunikációs rendszerét”, amelybe születtünk (Birdwhistell, 1970). Beszédszerveink megtanulják, hogyan formáljanak szigorúan konvencionális artikulált hangokat, intonációs kifejezéseket és strukturált beszédegységeket (kötetlen hangadások helyett). Testünk társas helyzetekben tanulja, hogyan végezhet mintakövetö gesztusokat (kötetlen mozdulatok helyett), amelyeket ,társadalmi kötöttségek” (Gumperz, 1964) határoznak meg. Röviden: nem pusztán beszélővé, hanem nyelvünk társas „előadójává” fejlődünk, aki az interakciók szinterén (Goffman, 1983) cselekszik, beszél, és tölti élete minden pillanatát.

A beszéd eredendő „performativitása” (Schechner, 2003) a nyelv lényegi öszszetevője, mégis sokszor megfeledkeznek erről az oktatáselmélet fősodrához tartozók: ritkán hajlandók felismerni, hogy a tanulás tere az elöadás tere lehet, a pedagógia dramaturgia, a tanóra pedig „szemtől-szembe érintkezés” (Hymes, 1964). Jelen cikkemben igyekszem megmutatni: még mindig nagyon kellene az oktatásban „a színész minimálmodellje” (Goffman, 1967), hogy oktató és diák együtt jelölhessék ki az elsődleges tanítási-tanulási forgatókönyv alapvető „testközelség-kezdőpontját" (Goffman, 1983), és minden résztvevő képzett, a beszéd drámai eszköztárát a lehető legjobban hasznosító szociális szereplővé váljék (Tauber-Sargent Mester, 2007).

\section{A JELENTÉS ELŐADÁSA}

Beszéd közben társas-fizikai térbe állítjuk testünket, akárcsak a színész a színpadon. A beszéd mindennapi „dramaturgiája” révén másoknak „bemutatott” énünk (Goffman, 1959) érzékelö, mozgó és gondolkodó én, amely sokféle szimbolikus akcióban (Kendon, 2004) teljességében vesz részt, „,bevonódik”. A szimbolikus 
akció - neve is sugallja - dinamikus folyamat, amely a teret és a testmozgást reprezentációs eszközként használja. A beszélő előtti tér - az úgynevezett ,gesztustér" - expresszív és ideacionális, kifejező-fogalomképző jellemzőkkel bír (McNeill, 1992, 2005; Calbris, 2011). Ugyanakkor interakciós tér (a közvetlen kommunikatív érintkezés színhelyéül szolgál), narrativv tér (események leírására, helyhez kötésére és összekapcsolására szolgál) és konceptuális tér (itt lehet formába önteni, megmutatni és összekapcsolni fogalmakat és érveket). Mivel beszédünk nagyrészt emotív, narratív és argumentatív összetevőkből áll, a különböző terek összeolvadnak egy szemiotikai térben, amelyet sok-sok jelentéshordozó verbális (a beszédet kísérő), koverbális és nemverbális jel tölt be. Bármi a beszéd célja - kérés, érzelemkifejezés, elbeszélés vagy tapasztalatelemzés - a diskurzusteret felhasználva és testünket megmozgatva igyekszünk befolyásolni - lehetőség szerint irányítani - a megszólított gondolatait és viselkedését.

Érdekes módon minél elvontabb és összetettebb egy téma, annál inkább folyamodnak a beszélők kinetikus képekhez, hogy világossá, elérhetővé tegyék jelentését. A tanár, a tudós rendszerint diagramokat rajzol, hogy olvasói, hallgatói könnyebben megértsék a nehéz vagy többféleképpen értelmezhető kérdéseket. Sematikus vonalakat vagy ábrákat vázolnak fel, amelyek ,,alakot adnak a fogalomnak", és kiemelik a legfőbb jellemzőket (Arnheim, 1969). A beszélő akkor is többet mozog, ha fogós kérdéssel kell megbirkóznia, és elmélyed a probléma megoldásában (Goldin-Meadow, 2015). Tehát ,,az absztrakt gesztusai” (McNeill, 1992), amelyek beszéd közben ösztönösen keletkeznek, egyértelmüen ,segítenek" (Goldin-Meadow, 2010): a mozdulatok serkentik a beszélő gondolatait is, miközben láthatatlan mentális múveleteket mások számára megfoghatóvá, elérhetővé tesznek. Bár igen nagy eltérések lehetnek aszerint, hogy ezt ki hogyan éri el, egy-egy beszélő következetesen használja az absztrakt gesztikulációt: különböző fogalmakhoz különböző tereket (vagy helyeket) rendel, és összehangolja a gesztuscselekvést a mentális cselekvéssel (McNeill, 2005; Parrill-Stec, 2018).

Fontos, hogy felismerjük: a narratív vagy argumentatív diskurzusban elöforduló összes kézmozdulat - és általában a mozgásesemények - nemcsak kísérnek, hanem önmagukban is megvalósitanak (véghez visznek, beteljesítenek) alapvető kognitív müveleteket, például amikor megszámláljuk, hány tételünk van összesen és miből mennyi, térben és időben elhelyezünk eseményeket, meggyőződünk fogalmak vagy jelenségek valódiságáról, rangsorolunk, mérünk, összekapcsolunk, behatárolunk, befoglalunk vagy kizárunk, kötünk vagy oldunk, nyitunk vagy zárunk, összehasonlítunk vagy szembeállítunk, nagyítunk vagy kicsinyítünk, abbahagyunk vagy folytatunk, egyesítünk vagy elválasztunk, kibontunk vagy tömörítünk, felcserélünk (Calbris, 2011). Ennek során a fogalmakat, eseményeket és jelenségeket reifikáljuk és entifikáljuk: „,olgokra” váltjuk, amelyek megfoghatók, amelyekre rámutathatunk, és amelyek a diskurzustérben fiktíven manipulálhatók (McNeill, 1992; Lapaire, 2016a). Így a beszélő keze elméjének kiterjesztése 
lesz, a kognitív feldolgozás pedig szimbolikus térben, a tárgyalkotás és -manipuláció folyamataként jelenik meg. Mivel a jelentés „manu-fakturálisan” készül a befogadó szeme láttára, és térben alakítjuk, mutatjuk meg a fogalomalkotás tárgyait, az értelmi képesség egyfajta „gesztus-mesterséggé” válik (Streeck, 2009).

Minden beszélő képes jelentéseket alkotni és felidézni szimbolikus térhasználat és testmozgás révén. Mindenkinek megvannak az eszközei ahhoz, hogy teljességében, fizikailag is részt vegyen a ,hiánytalan és holisztikus" reprezentációs aktusokban (Jousse, 2005, 192.). Ez nemcsak ,az absztrakt gesztusaiban” mutatkozik meg, hanem az elöadás olyan rituális formáiban is, mint a vallási szertartás, a beavatási rítus, a szakrális vagy tradicionális tánc, amelyben a különböző kultúrákhoz tartozó emberek testestül-lelkestül részt vesznek (Jousse, 1974; GebauerWulf, 1998; Schechner, 2003). Az efféle testgyakorlatban a tér, a testrészek és a fizikai mozgás valamiféle elvont, mégis látható módon jelölővé válnak. Épp ezért kellene minden egyes oktatónak, bármit is tanít, arra törekednie, hogy jobban megértse a mozgásban megnyilvánuló „értelmes testet” (Streeck, 2009).

Jó kiindulópont lehet, ha az emberi testben rejlő temérdek vokális, vizuális és kinetikus lehetőség felderítésével kezdjük - követve a hajdani klasszikus retorika útmutatását (Quintilianus, 1913-1921). Hasznos lehet, ha videófelvételen rögzítjük, megfigyeljük és értékeljük a tanárok (beleértve a magunk) gesztusainak hatását - bár ezt elsőre furcsának, zavarónak érezhetjük. Bármilyen módszert választunk, fontos, hogy tudatosítsuk a tanítás-tanulás fizikai jellegét, tudomásul vegyük, hogy az osztályterem középpontjában a tanár és a tanulók teste áll, amely egyszerre társas és fizikai entitás. Ha ezt már elértük, kinesztéziás tevékenységeket összefüző óravázlatot készíthetünk a kísérletezéshez. A következő részben röviden leírom, hogyan tehetjük ezt, hogy a résztvevők végül úgy érezzék: ,a testesültség lelkesít” (Lindgren-Johnson-Glenberg, 2013).

\section{CSELEKVÉSBEN MEGJELENŐ ISMERETSZERZÉS ÉS MEGÉRTÉS AZ ELŐADÓTÉRBEN}

Mivel a testi akció és a mentális aktus a beszédben együtt hatnak - a fogalomképzés és a kifejezés szintjén egyaránt -, minden diák képes arra, hogy beszédtechnikai eszközökkel és mozdulatokkal felfedezzen bármilyen teret, legyen az szociális, interakciós, szemantikai, narratív, diszkurzív, történelmi, matematikai vagy akár asztrofizikai tér (Rollinde, 2017). A vizsgálódási folyamat a kinetikus szinten halad elöre, ennek során a tanuló test teljességében, cselekvően vesz részt az észlelés és fogalomalkotás eleven aktusaiban.

Bár a mühelymunka során megmarad „tanár” és „diák” hagyományos szerepe, az oktató felismerheti: ő itt koreográfus, aki a résztvevőket végigvezeti a mozdulatsorokon. Ugyanakkor rendező is, aki rövid, értelmet feltáró vagy megvilágitó erejü jeleneteket állít színpadra: végül mindenképp napvilágra kerül némi igaz- 
ság valamilyen nézetről vagy helyzetről; célja, hogy diákjai testüket is ,,beleadva-bevonva" másként és nagyobb intenzitással, tapasztalati úton ismerjenek meg valamely elképzelést vagy jelenséget.

Az első kinesztéziás tanulási foglalkozások alkalmával az oktató megtud valami fontosat önmagáról is: azt, hogy teste érzékletekre nyitott, mozgó tanító test; hogy számít a térbeli helyzete és kinetikus tevékenységének szintje; és többet tehet annál, mint hogy csak ül vagy áll a tanteremben. A tanító pozíciók és fizikai akciók skálája sokkal szélesebb, mint valaha gondolta: nyújtózkodhat, guggolhat, gördülhet, összeeshet, lekuporodhat, meghajolhat, szökellhet, futhat, ugorhat, ringatózhat, suttoghat, motyoghat, fütyülhet, sikíthat stb., hogy diákjaira jelentős hatást gyakorolva tanítsa tárgyát. Ugyanezt mondhatjuk a diák kötöttségektől megszabadított tanuló testéröl: felfedezi, hogy az óra során ö is aktívan részt vehet a csoporttársaival (és a tanárral) közös interakcióban és kollaboratív munkában.

Tulajdonképpen Erving Goffman (1983) „,testközelség-kezdőpontja” szolgál az iskola- vagy egyetemi épületen belül szervezett összes mühelyfoglalkozás alapjául, témájuktól vagy kitüzött céljaiktól függetlenül. A biztonságot nyújtó, hatékonyságot fokozó tanulási környezetet, amelyben a lehető legkevesebb a szociális, fizikai vagy érzelmi gátlás, az alábbiak teremtik meg:

- mások közvetlen jelenlétének tudatosítása érzékelés révén (szaglás, látás, hallás, tapintás);

- a test felkészítése egyszerű légző-, járás- és beszédtechnikai gyakorlatokkal, valamint a mühelytér felfedezése fizikai és szociális-interakciós dimenzióiban.

A „holisztikus tudásgyarapításhoz” és ,az emberi lény egészének bevonásához" (Jousse, 2005, 209.) elegendő időt és figyelmet kell fordítani a bemelegítésre. A felkészítő tevékenységek legyenek igazán „felkészítő””: tegyék lehetővé a résztvevők számára az átmenetet az egyik térből a másikba, az egyik tanulási stílusról a másikra, hogy végül teljes mértékben készen álljanak az elkövetkező tevékenységekre.

Az alább nagy vonalakban ismertetett kinesztéziás tanulási forgatókönyvek már sikeresnek bizonyultak francia iskolákban és európai egyetemeken:

- Mozgásban a nyelvelmélet: a nyelv formális (például: igeidők és -módok, szóalkotás) és szociális-interakcionális jellemzőinek (például: a „,saját csoport vagy az idegen csoporthoz tartozik”, „társas kapcsolat”) elemzése. Célja, hogy elvont fogalmakat és folyamatokat fizikailag, a ,visszajátszás” (franciául rejeu) irányított formáin keresztül (Jousse, 1974) vagy „koreografikus gondolkodással" (Forsythe, 2009) fedezzünk fel. ${ }^{2}$

\footnotetext{
${ }^{2}$ Részletesen lásd Lapaire, 2011, 2016a, $2016 b$.
} 
- Eleven irodalom: egy sokrétủ irodalmi mü redukálása a leglényegére, a megalkotását inspiráló jelentős események újrajátszásával (Lapaire-Duval, 2017). Célja, hogy rövid, de hatásos csoportelőadást hozzunk létre egymást követő (statikus vagy dinamikus) élőképekkel, kifejező mozdulat kitartásokkal, némajátékokkal és (hangadásokkal kísért) drámai pillanatokkal. Az első szakaszban a résztvevők Quintilianus módszerét alkalmazzák: az eredeti müvet tömör, egyszerübb formára alakítják, és a tömörebb változatot boncolgatják tovább. Az olykor tévesen haszontalan, meddő utánzásnak vélt „parafrázis” közvetítésével elmélkedhetnek a müről, és tanulhatnak.

- Mozgó idézetek: a tudományos vagy irodalmi diskurzus egy-egy darabjának megértése, befogadása és kivetítése. Célja, hogy fogalmakat teljességükben megtapasztaljunk, internalizáljunk és memorizáljunk, majd drámai eszközökkel megjelenítsünk. A résztvevők különböző hangulatokkal és előadásmódokkal kísérleteznek.

Az összes felsorolt tevékenységre igaz, hogy a performativitás - a jelentések és folyamatok cselekvő, fizikai megjelenítése - elválaszthatatlan lesz a megértéstöl. A mühelyfoglalkozásokat módszeresen - közvetlen megfigyeléssel, online kérdőívek és a diákok tanulási naplói révén - értékeljük (Lapaire, 2016a, 2016b). Az eredmények azt mutatják, hogy az efféle testi tapasztalatra épülő stratégiák erösítik a csoportkohéziót és a tanár-tanuló interakciót, csökkentik a csoporttársak közötti távolságtartást, serkentik a koncentrációt és az önreflexiót, ugyanakkor felébresztik a diákok kiváncsiságát és kreativitását. Bár a mủhelyfoglalkozásokat ritkán tekintik nélkülözhetetlennek a megértés és memorizálás szempontjából, a nagy többség mégis élénkitőnek, szemnyitogatónak éli meg ezeket az összejöveteleket. A foglalkozások hatására kezdik másként látni a korábban számukra idegen, nehéz vagy érdektelen témákat: fokról fokra kialakul az „élő” és „közeli” érzése, hogy végül az unalmas tantárgyakat is vonzóbbá, jelentőssé tegye. További próbák kellenek - és folynak is -, hogy erröl teljesebb képet kapjunk.

\section{4. ÖSSZEGZŐ MEGJEGYZÉSEK}

A politikustól, hírolvasótól, talkshow-házigazdától és más professzionális kommunikátoroktól eltérően a tanár és az egyetemi professzor hajlamos alulképzett nyilvános beszélóként viselkedni, többnyire nem alkalmaz tudatosan beszédtechnikai eszközöket, testmozdulatokat és interakciós stratégiákat. Mivel alig-alig van tudatában a beszéd fizikális és performatív jellemzőinek, azt sem tudja, hogyan használhatná ki jobban, kreatívabban a teret diákjaival. Épp ezért nem ismeri fel, milyen fontos szerepet játszik a testmozgás az absztrakcióban és az argumentációban. Marcel Jousse $(1974,2000)$ meggyőzően érvel, hogy az érzékelő és szín- 
padon cselekvő - ritmikusan mozgó és megszólaló - emberi test egésze az észlelés, a kifejezés és a megértés legfőbb közege. Nyugati oktatási rendszerünkben kifejlődött egyfajta „,könyvmoly-törzs”, amely csak az írás-olvasási készségeket értékeli. A magasabb rendü tudásformákat rendszerint a nyomtatott betü mozdulatlanságával, a könyvbe kövült tudással (scientia cum libro) teszik egyenlővé (Jousse, 2000, 26.).

Jousse bírálata ma is nagyrészt helytálló: még mindig a (nyomtatott vagy digitalizált) szöveg az első számú közvetítő a valóság és megismerése között. Ezért több időt vesz el az exegézis ${ }^{3}$ - az írott anyag kritikai értelmezése -, mint amenynyit a környező világ megfigyelésére fordítunk, és még mindig túl sok tanuló érezheti úgy, hogy „,mumifikálódik a nyomtatott lapok és könyvek szarkofágjában" (Jousse, 2000, 28.).

A gyerekeknél jól látható és szóbeliségre épülő kultúrákban nagyra értékelt „eleven, gesztusos elemet”, az emlékezetbe vésés és „visszajátszás” képességét még mindig többnyire lebecsülik a nyugati oktatás fösodrában. Csak a korai gyermekkorban tekintik a tanulót ,eleven teremtésnek". Óvodáskorában olyan nevelésben részesül, amely eredendően és tudatosan ,,scientia in vivo” (Jousse, 2000, 26.). De a fiatal tanuló testmozgékonyságát nem tűrik sokáig. Amint megjelenik a tantervben az írás-olvasás - általában öt-hat éves korban -, felülkerekedik a nyomtatott vagy digitalizált szöveg, mindenekfelett eluralkodik az írástudás. Bár ma már több érzékleti ingert biztosíthat a táblagép- vagy számítógép-használat, általánossá vált a mozgáshiány szinte minden tanteremben (kivéve persze a tánc-, dráma- és tornaórákat). Ez pedig oda vezet, hogy mozdulatlanná dermed a tudás és a tanulás is: „Számunkra ma a tudomány halálosan komoly dolog. Olyannyira, hogy már nem is tud továbbhaladni." (Jousse, 2005, 52.).

Lehet változtatni ezen? Jöhet-e változás valaha? A Gazdasági Együttmüködési és Fejlesztési Szervezet (OECD) megbízásából nemrégiben készült felmérés öszszegzése az „eredményes tanári munka feltételeinek megteremtéséről” (OECD, 2018) nem is említi a scientia in vivo elvet. Egy szóval sem utal arra, hogy a „testesültség” (vagy a „testi tudás”) „egyesítő elv” (Glenberg, 2010) lehetne az oktatásban, bár feltehetően „diák” és ,tanár” fizikailag érintkeznek a tanteremben, és - még ha nem is tudatosan - ,(valamelyest) testüket is használva adják jelét ismereteiknek" (Lindgren-Johnson-Glenberg, 2013, 445.). Az OECD-jelentés helyesen abból indul ki, hogy a tanár ,,a mai iskola legfontosabb erőforrása”. Tesz néhány hasznos megállapítást is: a tanár „nem valamiféle ipari futószalagnál dolgozó, lecserélhető munkás” (OECD, 2018, 168.), hiszen „megváltoztathat éle-

\footnotetext{
${ }^{3}$ E tanulmányban az exegézis jelentése magában foglal mindennemü, az írott szöveggel kapcsolatos értelmezési folyamatot. Tehát éppúgy vonatkozik arra, amikor a diák próbálja megfejteni a barátja sms-ét vagy Twitter-bejegyzését, mint arra, amikor a tudós igyekszik magyarázni bibliai szövegeket.
} 
teket” (OECD, 2018, 32.), és csakis ,jobb tanárok” alkalmazásával lehet ,javítani az iskolai oktatást" (OECD, 2018, 168.). Azt viszont egyáltalán nem határozza meg fiziológiai és fenomenológiai szinten, hogy mi teszi a tanárt „,jobbá”, mi javítja képzése, az általa adott órák és az elért „szakmai fejlődésének” „minőségét”, hogy mitől lesz hatékonyabb a „hátrányos helyzetü” diák felzárkóztatása, és hogy mitől válhat a „tantermi élmény” intenzívebbé, különlegessé. Nem meglepő, hogy a 'test' szót - amely mindössze négyszer fordul elö a 168 oldalas jelentésben - egyszer sem használja elsődleges fizikai értelmében. Mégis némi reménykedésre adhat okot, hogy a „,kiemelkedően teljesítő országok” többet fektetnek „tanárfelkészítő programokba” és az egész életen át tartó tanulásba. A tanártól elvárható, hogy „tudásvágyó szakember” módjára viselkedjen (OECD, 2018, 131.), és rendszeresen vegyen részt ,az iskola által szervezett mühelyfoglalkozásokon" (OECD, 2018, 32.). Tapasztalatom szerint az efféle foglalkozások remek lehetőséget nyújthatnak a tanároknak, hogy elgondolkozzanak azon, milyen csodákat érhetnek el diákjaikkal együtt a tanulási térben gondolkodó és mozgó testük révén. Merthogy igenis lehet változtatni, és van jövője a jobb oktatási gyakorlatnak, amely a test cselekedtetésével serkenti, fenntartja, sőt javítja a mentális cselekvést. De még hosszú utat kell megtennünk e változásig, és olykor magunkra maradhatunk.

\section{IRODALOM}

Arnheim, R. (1969): Visual Thinking. Berkeley: University of California Press

Birdwhistell, R. (1970): Kinesics and Context. Philadelphia: University of Philadelphia Press Calbris, G. (2011): Elements of Meaning in Gesture. Amsterdam-Philadelphia: John Benjamins

Forsythe, W. (2009): Synchronous Objects as a Choreographic Object. Interview Recorded at the Ohio State University. In: Conversation with Professor Norah Zuniga-Shaw. https://www.youtube.com/watch? $\mathrm{v}=\mathrm{uQdZBOVYLdI}$

Gebauer, G. - Wulf, Ch. (1998): Spiel - Ritual - Geste. Mimetisches Handeln in der sozialen Welt. Reinbek: Rowohlt

Glenberg, A. M. (2010): Embodiment as a Unifying Perspective for Psychology. Cognitive Science, 1, 4, 586-596. DOI: 10.1002/wcs.55

Goffman, E. (1959): The Presentation of Self in Everyday Life. New York: Anchor Books. Magyarul: Goffman, E. (2000): Az én bemutatása a mindennapi életben (ford. Berényi G.). Budapest: Thalassa Alapítvány-Pólya Kiadó

Goffman, E. (1967): Interaction Ritual: Essays on Face-to-Face Behavior. New York: Pantheon Books

Goffman, E. (1983): The Interaction Order. American Sociological Association, 1982 Presidential Address. American Sociological Review, 48, 1, 1-17.

Goldin-Meadow, S. (2010): Hearing Gesture: How Our Hands Help Us Think. Cambridge, Mass.: The Belknap Press of Harvard University Press

Goldin-Meadow, S. (2015): From Action to Abstraction: Gesture as a Mechanism of Change. Developmental Review, 38, 167-184. DOI: 10.1016/j.dr.2015.07.007 
Gumperz, J. J. (1964): Linguistic and Social Interaction in Two Communities. American Anthropologist, 66, 6 (Part 2), 137-153. DOI: 10.1525/aa.1964.66.suppl_3.02a00100

Hymes, D. (1964): Toward Ethnographies of Communication. American Anthropologist, 66, 6 (Part 2), 1-34. DOI: 10.1525/aa.1964.66.suppl_3.02a00010

Jousse, M. (1974): L'Anthropologie du Geste. Paris: Gallimard

Jousse, M. (2000): The Anthropology of Geste and Rhythm. Second revised edition, edited from the original French [1974-78] by E. Sienaert and translated in collaboration with J. Conolly. Durban, South Africa: Mantis Publishing

Jousse, M. (2005): The Fundamentals of Human Expression and Communication. Seven Lectures by Marcel Jousse. Translated and presented by E. Sienaert and J. Conolly. Durban, South Africa: Mantis Publishing

Kendon, A. (2004): Gesture: Visible Action as Utterance. Cambridge: Cambridge University Press

Lapaire, J.-R. (2011): Visuo-kinetic Explorations of Grammar. In: Benedek A. - Nyíri K. (eds.): Images in Language: Metaphors and Metamorphoses (Visual Learning 1). Frankfurt: Peter Lang, 41-55. https://halshs.archives-ouvertes.fr/halshs-01629049/document

Lapaire, J.-R. (2016a): From 'Ontological Metaphor' to Semiotic Make-Believe: Giving Shape and Substance to Fictive Objects of Conception with the 'Globe Gesture'. Signo, 41, 70. https:// halshs.archives-ouvertes.fr/halshs-01628902/document

Lapaire, J.-R. (2016b): The Choreography of Time: Metaphor, Gesture and Construal. In: Gabriel, R. - Pelosi, A. C. (eds.): Linguagem e cognição: emergência e produção de sentidos. Florianópolis: Insular, 217-234.

Lapaire, J.-R. - Duval, H. (2017): To the Lighthouse (1927): A Choreographic Re-elaboration. Miranda, 15. https://journals.openedition.org/miranda/10898

Lindgren, R. - Johnson-Glenberg, M. (2013): Emboldened by Embodiment: Six Precepts for Research on Embodied Learning and Mixed Reality. Educational Researcher, 42, 8, 445-452.

McNeill, D. (1992): Hand and Mind: What Gestures Reveal about Thought. Chicago: The University of Chicago Press

McNeill, D. (2005): Gesture and Thought. Chicago: The University of Chicago Press

OECD (2018): Effective Teacher Policies: Insights from PISA. Paris: OECD Publishing DOI: 10.1787/9789264301603-en

Parrill, F. - Stec, K. (2018): Gestures of the Abstract. Pragmatics \& Cognition, 24, 1, 33-61. DOI: 10.1075/pc.17006.par

Quintilianus, M. F. (1913-1921): Libri de institutione oratoria (Institutio oratoria). Magyarul: M. Fabius Quintilianus szónoklattana (ford. Prácser A.). I-II. Budapest: Franklin-Társulat

Rollinde, E. (2017): Learning Science through Enacted Astronomy. International Journal of Science and Mathematics Education, 1-16. DOI: 10.1007/s10763-017-9865-8

Schechner, R. (2003): Performance Theory. Second Edition. New York: Routledge

Streeck, J. (2009): Gesturecraft: The Manu-Facture of Meaning (Gesture Studies 2). Amsterdam: John Benjamins

Tauber, R. T. - Sargent Mester, C. (2007): Acting Lessons for Teachers: Using Performance Skills in the Classroom. Second Edition. Westport, CT: Praeger Publishers 